Mimo powyższej uwagi należy podkreślić, że książka Niklewskiej daje spójny i syntetyczny obraz aktywności Dmowskiego jako działacza niepodległościowego. Pokazuje kunszt i skuteczność jego działalności dyplomatycznej. Warto o tym pamiętać, aby nie patrzeć na Dmowskiego jedynie poprzez pryzmat jego antysemityzmu i antyżydowskich fobii.

Ilona Zaleska (Toruń)

\title{
Maciej Matwijów, Mieczysław Gębarowicz (1893-1984). Uczony i opiekun narodowych dóbr kultury, Warszawa 2013, ss. 543
}

$\mathrm{M}$ ieczysław Gębarowicz urodził się 17 XII 1893 roku w Jarosławiu, w polskiej rodzinie inteligenckiej. W 1918 roku wstąpił ochotniczo do Wojska Polskiego, z którego wystąpił po zawarciu polsko-ukraińskiego zawieszenia broni. W październiku 1921 roku ukończył studia z zakresu historii sztuki na Wydziale Filozoficznym Uniwersytetu Lwowskiego, uzyskując tytuł doktora filozofii. Rok później podjął pracę w Zakładzie Narodowym im. Ossolińskich we Lwowie. W 1924 roku został kierownikiem Muzeum im. Lubomirskich we Lwowie, następnie został mianowany kustoszem tejże instytucji, z zatrzymaniem kierownictwa Biblioteki Pawlikowskich. Do wybuchu II wojny światowej miał ogromny udział w zakresie kształtowania polityki gromadzenia zbiorów Muzeum oraz mógł poszczycić się wzbogaceniem instytucji w tym czasie o około 20 tys. nowych jednostek. Na podstawie pracy „Początki kultu św. Stanisława i jego średniowieczny zabytek w Szwecji” uzyskał habilitację w 1928 roku, a profesurę tytularną 
na Uniwersytecie Jana Kazimierza we Lwowie w 1936 roku. Szybko pozyskał autorytet w środowisku naukowym, a w metodologii badań, w dziedzinie historii sztuki kładł szczególny nacisk na umiejętności stosowania analizy artystycznej i historycznej. W czasie II wojny światowej pełnił obowiązki dyrektora Zakładu Narodowego im. Ossolińskich we Lwowie. W 1945 roku został członkiem czynnym Polskiej Akademii Umiejętności. Pod koniec konfliktu oraz już po jego zakończeniu był usilnie namawiany przez przedstawicieli polskiego środowiska naukowego do przyjazdu na lewą stronę Bugu, podjął jednak samodzielną decyzję o pozostaniu we Lwowie (do końca życia uważał, że miasto znajduje się pod okupacja) i wziął czynny udział w rewindykacji zbiorów Ossolineum. Na podstawie wspomnianej decyzji został zmuszony do zrezygnowania z perspektyw dalszej kariery naukowej. Był obiektem ataków i szykan, oskarżony o „burżuazyjny nacjonalizm" został zdegradowany i zwolniony z pracy (pracował później w różnych instytucjach, m.in. na stanowisku młodszego pracownika naukowego). W 1963 roku został przeniesiony na emeryturę oraz otrzymał zakaz korzystania ze zbiorów rękopiśmiennych i archiwalnych najważniejszych instytucji naukowych Lwowa. Gębarowicz zmarł 2 września 1984 roku we Lwowie. Bezsprzecznie należy do najwybitniejszych polskich historyków sztuki ubiegłego stulecia oraz przedstawicieli humanistycznej inteligencji lwowskiej. Był uznanym autorytetem, nigdy nie odstępował od przyjętych zasad i ideałów. W trakcie przyjazdów do powojennej Polski był witany w środowisku naukowym jak bohater narodowy ${ }^{1}$.

Autorem pracy „Mieczysław Gębarowicz (1893-1984). Uczony i opiekun narodowych dóbr kultury” jest prof. Maciej Józef Matwijów (ur. w 1958 roku), historyk, wieloletni pracownik Działu Rękopisów w Bibliotece Zakładu Narodowego im. Ossolińskich we Wrocławiu. Obecnie pracuje w Instytucie Informacji Naukowej i Bibliotekoznawstwa na Wy-

1 Podstawowe informacje o Gębarowiczu na podstawie: J. Draus, Mieczystaw Gębarowicz, „Studia Rzeszowskie” 1996, t. 3, s. 191; M. Matwijów, Lwowskie Ossolineum w listach Mieczystawa Gębarowicza z lat 1943-1946, „Czasopismo Zakładu Narodowego im. Ossolińskich" 1992, z. 1, s. 157-192; idem, Mieczystaw Gębarowicz (1893-1984) ostatni dyrektor lwowskiego Ossolineum, „Czasopismo Zakładu Narodowego im. Ossolińskich” 1992, z. 1, s. 12; idem, Mieczystaw Gębarowicz (1893-1984). Uczony i opiekun narodowych dóbr kultury, Warszawa 2013, passim. 
dziale Filologicznym Uniwersytetu Wrocławskiego. Jest autorem wielu publikacji oraz artykułów dotyczących dziejów politycznych Rzeczypospolitej szlacheckiej w XVII wieku, historii lwowskiego Ossolineum i polskich dóbr kultury we Lwowie oraz problematyki staropolskiej książki rękopiśmiennej. 20 III $1991 \mathrm{roku}$, na podstawie swojej dysertacji doktorskiej „Ostatnie sejmy przed abdykacją Jana Kazimierza 1667 i 1668” na Uniwersytecie Wrocławskim, uzyskał stopień doktora nauk humanistycznych w zakresie historii, o specjalności: historia nowożytna Polski. Z kolei 22 IX 2004 roku na tej samej uczelni uzyskał stopień doktora habilitowanego nauk humanistycznych w zakresie historii, o specjalnościach: historia nowożytna oraz historia najnowsza. Jego rozprawa habilitacyjna nosi tytuł „Zakład Narodowy im. Ossolińskich w latach 1939-1946”. Praca ta została opublikowana przez wydawnictwo Ossolineum ${ }^{2}$.

Wśród licznych artykułów naukowych oraz większych publikacji z zakresu historii nowożytnej Polski i historii kultury XIX-XX wieku autorstwa prof. Matwijowa warto wspomnieć o następujących opracowaniach: „Lwowskie Ossolineum w listach Mieczysława Gębarowicza z lat 1943-1946”, „Mieczysław Gębarowicz (1893-1984). Ostatni dyrektor lwowskiego Ossolineum”, czy „Geneza abdykacji Jana Kazimierza Wazy 1662-1668” - wszystkie trzy wymienione wyżej artykuły zostały opublikowane w „Czasopiśmie Zakładu Narodowego im. Ossolińskich” we Wrocławiu kolejno w 1992, 1993 i 2000 roku. W 2009 roku w czasopiśmie „Zapysky Lwiwśkoji nacjonalnoji naukowoji biblioteky imeni W. Stefanyka” opublikowany został artykuł „Współpraca Mieczysława Gębarowicza z nauką ukraińską w latach 1946-1984”, z kolei w 2011 roku w „Przeglądzie Wschodnim” zamieszczony został artykuł „Kontakty Mieczysława Gębarowicza z Krajem w latach 1946-1984 (karta z życia Polaków we Lwowie po II wojnie światowej)". Innymi publikacjami w formie książkowej autora recenzowanej pracy są na przykład: wspomniana praca doktorska „Ostatnie sejmy przed abdykacją Jana Kazimierza 1667-1668”, „Walka o lwowskie dobra kultury w latach 1945-1948”, czy także wymieniona

${ }^{2}$ http://nauka-polska.pl/dhtml/raporty/ludzieNauki?rtype=opis\&objectId=17186 \&lang=pl, [dostęp: 21.12.2016]; http://dzielautracone.gov.pl/aktualnosci/95-konferencja-zrabowane-odzyskane-dobra-kultury-przypadek-polski [dostęp: 21.12.2016] 
przeze mnie rozprawa habilitacyjna, „Zakład Narodowy im. Ossolińskich w latach 1939-1946" - wszystkie trzy pozycje zostały wydane przez Towarzystwo Przyjaciół Ossolineum we Wrocławiu odpowiednio w 1992, 1996 i 2003 roku.

Tematyka historii Zakładu Narodowego im. Ossolińskich we Lwowie oraz biografia Mieczysława Gębarowicza leżą w głównym nurcie zainteresowań badawczych prof. Matwijowa. Ponadto, we wstępie do książki „Mieczysław Gębarowicz (1893-1984). Uczony i opiekun narodowych dóbr kultury" podkreśla on, że praca jest efektem jego długoletniego, sięgającego końca lat osiemdziesiątych, zainteresowania osobą i działalnością Gębarowicza, do czego pierwszym impulsem były znajdujące się w Dziale Rękopisów Zakładu Narodowego im. Ossolińskich we Wrocławiu materiały rękopiśmienne dotyczące tej postaci.

We wstępie pracy autor wymienia najważniejsze artykuły, których tematyka skupiona była wokół postaci Gębarowicza. Informuje o publikacjach z lat osiemdziesiątych minionego wieku, których autorzy znali osobiście ich bohatera. Prof. Matwijów zaznacza przy tym, że prace te są niezwykle cenne ze względu na ich szczegółowość, wieloaspektowość ujęcia postaci oraz dużą rzetelność faktograficzną. Wymienia ponadto artykuły ukazujące sylwetkę Gębarowicza od strony jego życia prywatnego, a także publikacje, które zaczęły powstawać począwszy od lat dziewięćdziesiątych $\mathrm{XX}$ wieku, tworzone przez znakomitych polskich historyków i historyków sztuki, by wymienić tylko Jerzego Wyrozumskiego czy Mieczysława Zlata, które w sposób kompetentny omawiały działalność naukową Gębarowicza i przybliżały jego dorobek na tle osiągnięć nauki polskiej. Autor informuje również, że działalność tego wybitnego polskiego historyka sztuki, z punktu widzenia nauki ukraińskiej, przedstawił Borys Woznicki. Prof. Matwijów we wstępie swojej pracy wymienił także własne publikacje dotyczące Gębarowicza oraz zwrócił uwagę na prace naukowe i popularnonaukowe prezentujące - w jego opinii - wprost żenujący poziom, a których skutkiem jest powielanie przez kolejnych autorów błędów, przeinaczeń i konfabulacji w pracach ukazujących się po roku 2000.

Biorąc pod uwagę wspomniane powyżej fakty (nierzetelne opracowania naukowe) oraz brak kompleksowej biografii Mieczysława Gębarowicza, prof. Matwijów zdecydował się na całościowe jej opracowanie. Autor zazna- 
czył we wstępie, że praca mogła powstać w 2013 roku, dzięki uzyskaniu dostępu do ważnych materiałów biograficznych, bez których jej opracowanie byłoby przedwczesne.

We wstępie prof. Matwijów opisuje, że w związku z kolejami życia Mieczysława Gębarowicza, który mimo tego, iż prawie w całości spędził je w jednym mieście, to jednak w „zmieniających się warunkach”, o całkowicie odmiennej specyfice politycznej, ustrojowej i narodowościowej, zdecydował się na przyjęcie chronologicznego schematu konstrukcyjnego, w którym można wyróżnić trzy duże bloki zagadnieniowe. Pierwszy z nich obejmuje okres do wybuchu II wojny światowej; drugi dotyczy największego konfliktu w dziejach ludzkości i kilkunastu miesięcy po jego zakończeniu; trzeci związany jest z pozostaniem Gębarowicza na stałe w USRR. Autor podkreślił przy tym, że bloki te nie są równomierne poprzez ich zakres chronologiczny, obfitość materiałów źródłowych, dynamikę rozgrywanych zdarzeń czy, wreszcie, rolę odgrywaną przez samego Gębarowicza. Dlatego też pod względem objętości dominuje okres powojennej działalności bohatera, który stanowi nieco ponad połowę całej pracy. Z kolei największą szczegółowością cechuje się okres najkrótszy - czasy II wojny światowej. Jest on najbardziej obfitujący w kluczowe wydarzenia, których skutki rzutowały na późniejsze życie Gębarowicza. Autor publikacji podkreślił ponadto, że przyjęcie tego schematu konstrukcyjnego zadecydowało o podwójnym ujęciu działalności i dorobku naukowego bohatera opracowania - osobno dla lat międzywojnia i osobno dla okresu powojennego (s. 7-14).

We wstępie autor nie wyjaśnia ram chronologicznych pracy. Odpowiadają one okresowi życia Gębarowicza zawartemu w tytule - od 1893 do 1984 roku - choć fakty zawarte w pracy nie kończą się wraz z ostatnią wspomnianą datą. Autor w sposób jasny i precyzyjny w pierwszym rozdziale zapoznaje czytelnika $\mathrm{z}$ informacjami dotyczącymi najbliższej rodziny oraz młodości bohatera. Biografię rozpoczyna fakt przyjścia Gębarowicza na świat, czyli data 17 XII 1893 roku. Natomiast ostatni rozdział monografii wykracza poza 2 IX 1984 roku (dnia śmierci bohatera). Autor krótko i przejrzyście informuje czytelnika o formach uczczenia pamięci Gębarowicza głównie w latach osiemdziesiątych i dziewięćdziesiątych ubiegłego stulecia, które dokonały się w tym czasie poprzez publikacje artykułów jemu poświęconych w polskiej (także emigracyjnej) prasie, organizowanie 
wieczorów oraz wystaw przez różne muzea i stowarzyszenia, uhonorowanie go przez rodzinne miasto poprzez nazwanie jego imieniem jednej z ulic, kończąc na opracowaniu solidnego biogramu Gębarowicza w ukraińskiej Encyklopedii Lwowa w 2007 roku. W mojej opinii jest to zupełnie zrozumiałe, bowiem ujęcie tych informacji w pracy składa się w logiczną całość, a ona sama nie zostaje „urwana” wraz ze śmiercią jej bohatera.

Podstawą źródłową monografii są bogate materiały archiwalne i rękopiśmienne, co świadczy o szerokiej znajomości ich przez autora, a także o solidnie przeprowadzonej kwerendzie. Najważniejszymi materiałami, z których przede wszystkim czerpał autor, była spuścizna Gębarowicza, znajdująca się, zgodnie z wolą samego twórcy, w Bibliotece Zakładu Narodowego im. Ossolińskich we Wrocławiu. Warto podkreślić, że począwszy od lat dziewięćdziesiątych ubiegłego stulecia była ona uzupełniana przez prof. Matwijowa. Autor pracy o Gębarowiczu korzystał ponadto z jego materiałów autobiograficznych, innych spuścizn polskich historyków sztuki i dokumentacji aktowej wielu instytucji. Kwerenda została zrealizowana łącznie w granicach czterech państw: Polski, Ukrainy, Niemiec i Francji. Prof. Matwijów wykorzystał materiały gromadzone w wielu instytucjach, by wymienić tylko: Bibliotekę Zakładu Narodowego im. Ossolińskich we Wrocławiu, Archiwum Nauki Polskiej Akademii Nauk i Polskiej Akademii Umiejętności w Krakowie, Bibliotekę Jagiellońską, Lwowską Naukową Narodową Bibliotekę im. Wasyla Stefanyka NAN Ukrainy, Państwowe Archiwum Obwodu Lwowskiego we Lwowie czy Centralne Państwowe Archiwum Historyczne Ukrainy we Lwowie. Autor skorzystał także z różnego rodzaju wspomnień o Gębarowiczu, z prasy i opracowań, wykazując się przy tym znajomością aktualnego stanu badań nad jego postacią, przeprowadził ponadto wywiady $\mathrm{z}$ dwoma ukraińskimi naukowcami i muzealnikami, znającymi osobiście bohatera opracowania.

W recenzowanej przeze mnie pracy autor realizuje swoje założenia zaznaczone we wstępie, a wspomniane trzy różne bloki zagadnieniowe można wyróżnić. Polemice można poddać brak oficjalnego, technicznego podziału opracowania na trzy główne części, co utrudnia czytelnikowi lekturę. Zadając sobie pytanie, czy opracowanie byłoby wówczas bardziej przejrzyste, a sama ocena całościowa postaci Gębarowicza, jego wszechstronnej działalności i wielkiego dorobku łatwiejsza, wydaje się, że można skłaniać się 
ku odpowiedzi twierdzącej. Ponadto, podążając tymi kategoriami, brakuje - w mojej opinii - następujących po sobie, całościowych podsumowań wspomnianych przez autora trzech bloków zagadnieniowych. Publikacja liczy 543 strony. Po lekturze 16 rozdziałów, czyli po 509 stronach, autor w sposób bardzo ogólny w „Uwagach końcowych”, w zawartym na niecałych trzech stronach tekście dokonuje oceny Mieczysława Gębarowicza. Wspomniałem wcześniej o braku kolejnych podsumowań trzech głównych bloków tematycznych. Jednakże, skoro nie zostały one oficjalnie przez autora wyodrębnione, to niezwykle trudne jest znalezienie odpowiedzi na pytanie, dlaczego całościowe podsumowanie postaci Gębarowicza, uczonego i opiekuna narodowych dóbr kultury, zostało zawarte bardzo krótko oraz ogólnikowo. Jest to tym bardziej zastanawiające, bowiem z lektury prof. Matwijowa, opartej na przecież bardzo solidnej podstawie źródłowej i budzącej podziw wieloaspektowej znajomości przebiegu życia oraz zawartej w nim działalności bohatera opracowania przez autora, Gębarowicz wyłania się jako postać wielka, prostolinijna, wręcz kryształowa, wreszcie bezdyskusyjnie zaliczana do najbardziej zasłużonych osobistości polskiej nauki i kultury XX wieku. W związku z tym próba szczegółowego, całościowego podsumowania postaci Gębarowicza byłaby cenna oraz wskazana.

Praca nie jest biografią kontekstowo-pretekstową. Autor, ukazując jednak tło wydarzeń i skupiając swoje wysiłki na jak najszerszym przedstawieniu sylwetki bohatera, uwzględnił również podstawowe informacje dotyczące grupy współpracowników Gębarowicza. Celem autora nie było porównanie głównego bohatera $\mathrm{z}$ innym lub innymi jemu odpowiadającymi osobami, reprezentującymi ówczesne polskie środowisko naukowe historyków sztuki. Ponadto, z lektury wynika, że w powojennym Lwowie, nie znajdziemy osoby, z którą można by porównać bohatera książki. Należy jednak dodać, że na podstawie bogatej korespondencji, na której bardzo mocno opierał się autor, bohater nie jest oczywiście pozbawiony wad.

Praca prof. Matwijowa jest opracowaniem naukowym, recenzowanym przez prof. Jakuba Lichańskiego z Wydziału Polonistyki Uniwersytetu Warszawskiego i prof. Mieczysława Zlata, nieżyjącego już pracownika Instytutu Historii Sztuki Uniwersytetu Wrocławskiego oraz przewodniczącego Rady Naukowej Zakładu Narodowego im. Ossolińskich we Wrocławiu. W swo- 
jej pracy autor posługuje się wspaniałą, bogatą polszczyzną, zaopatruje ją w przypisy, zaś bibliografia podzielona jest na kilka części: materiały archiwalne i rękopiśmienne, zbiory prywatne, wydawnictwa źródłowe, wspomnienia i dzienniki drukowane oraz opracowania. Tytuł książki jest adekwatny do jej zawartości. W pracy znajduje się wykaz ważniejszych skrótów, aż 50 ilustracji, świetnie wzbogacających i urozmaicających lekturę oraz ich spis, indeks osobowy, a także - co niezmiernie ważne - aneks, zawierający wszystkie 87 prac naukowych (wydanych lub nie) Mieczysława Gębarowicza. Na okładce widzimy fotografię przedstawiającą bohatera opracowania. Wybór właśnie tej ilustracji jest - w mojej opinii - bardzo trafny: skupiony podczas pracy Gębarowicz znajduje się w Bibliotece Pawlikowskich we Lwowie w 1926 roku. Fotografia ta idealnie koresponduje z tytułem, a po lekturze książki czytelnik ma wrażenie, że stanowi ona symboliczny obraz bohatera.

Praca została opublikowana w 2013 roku przez warszawskie wydawnictwo DiG. Odnośnie do pracy prof. Matwijowa należy dodać, że jej wydanie zostało dofinansowane przez Instytut Informacji Naukowej i Bibliotekoznawstwa Uniwersytetu Wrocławskiego, dzięki staraniom Polskiego Towarzystwa Heraldycznego w ramach projektu badawczego. Nie została podana informacja o nakładzie opracowania. Autor ponadto związany jest $\mathrm{w}$ swojej pracy naukowej głównie $\mathrm{z}$ wydawnictwem Ossolineum, dlatego wydaje się wielce prawdopodobne, że jego współpraca z Wydawnictwem $\mathrm{DiG}$ jest jak na razie jednorazowa.

Recenzowana przeze mnie praca jest efektem wieloletnich badań naukowych, solidnie przeprowadzonej kwerendy oraz potwierdzeniem wieloaspektowej znajomości przebiegu życia, będących wynikiem zainteresowań osobą Gębarowicza. Dzięki żmudnej, ale efektywnej pracy autora nad niezwykle bogatymi materiałami, udało mu się stworzyć kompleksową biografię jednej z najbardziej zasłużonych osobistości polskiej nauki i kultury ubiegłego stulecia. Pozycja ta jest niezwykle cenną biografią historyka sztuki i muzealnika. Z całą pewnością wzbogaca naszą wiedzę na temat historii Zakładu Narodowego im. Ossolińskich we Lwowie, jego pracowników i zbiorów, a także samego Lwowa. Jest to pozycja bezsprzecznie godna uwagi, stanowiąca zarazem wzór biografii wybitnego uczonego. 
